\title{
Original Article Comprative Study between using Local Corticosteroid, Systemic Beta- Blockers and Combined Therapy in Manegment of Heamangioma in Pediatrics
}

\author{
A.A.Salem ${ }^{1}$, N.M.Dessouky ${ }^{2}$, M.E.Abdel Latif ${ }^{1}$ and W.M.Mostafa ${ }^{1}$ \\ ${ }^{1}$ General Surgery Dept., Faculty of Medicine, Benha Univ., Benha, Egypt \\ ${ }^{2}$ pediatric Surgery Dept., Faculty of Medicine, Cairo Univ., Cairo, Egypt \\ E-Mail:waled,mo7med@gmail.com
}

\begin{abstract}
Infantile hemangiomas (IHs), the most common tumor of childhood. For many years, the first-line medical treatment for complicated lesions was corticosteroids, including topical, intralesional, and systemic approaches. However, a major breakthrough occurred in 2008 observed that a group of children with IH who received therapy with the nonselective beta-blocker propranolol experienced marked improvement in their lesions. This examine meant will think about the middle of those impact of utilizing neighborhood corticosteroids (metamethasone), systemic beta blocker (Propranolol) and both consolidated in the management about heamangiomas in pediatrics. This might have been a prospective consider that led during Benha college clinic What's more Benha Youngsters doctor's facility on tolerant with heamangioma. Patients for heamangioma who match consideration criteria were isolated haphazardly under three groups: aggregation a : 20 patients in this one assembly might have been undergone intralesional infusion for corticosteroid (betamethasone) during An measurements of 10 with $40 \mathrm{mg} / \mathrm{ml}$ On 5 differentiate sessions with a interim from claiming 3 weeks. Assembly B: 20 patients in this bunch were provided for oral b-blocker (propranolol) for 2$3 \mathrm{mg} / \mathrm{kg} / \mathrm{day}$ to 4 months. Bunch C: 20 tolerant in this one assembly were provided for both oral B-blocker (Propranlol) Furthermore intralesional infusion from claiming corticosteroid (Betamethasone) to 4 months. There might have been statistically huge between gathering An and aggregation $\mathrm{b}$ over bunch $\mathrm{C}$, in regards repeat then afterward $6 \mathrm{~m}$. No repeat struck them Around gathering C, repeat happened for 20\% Around bunch B, 10\% in bunch An. Mean Contrast about aggregation a (18. 90), bunch b (12. 64) Also bunch c (19. 38), thereabouts assembly c's will be superior to assembly A, one assembly $\mathrm{b}$. There were statistically huge certain unique hemangioma size $(\mathrm{cm})$ Furthermore extent at 6 months "around gathering $\mathrm{C}$, However no statistically huge connection the middle of unique hemangioma size $(\mathrm{cm})$ Also size at 6 months "around aggregation An What's more bunch b. We discovered fundamentally preferred Conclusion in the joined medicine aggregation contrasted with monotherapy aggregations.
\end{abstract}

Key words: Local corticosteroid-Systemic Beta-blockers, Combined therapy, Heamangioma.

\section{Introduction}

Childish hemangiomas (IHs), those The greater part as a relatable point tumor about childhood, would considerate proliferations from claiming vascular endothelium. However regularly not obvious In the time from claiming birth, shallow hemangiomas as a rule show up on the skin inside the principal month from claiming life Likewise brilliant red papules or plaques. Profound hemangiomas might detract more with create What's more regularly show up as skincolored on pale blue subcutaneous swellings. In spite of the fact that large portions IH won't result in noteworthy problems, An little subset will bring about difficulties for example, such that ulceration, bleeding, practical impairment, alternately changeless cosmea disfigurement. Rarely, hemangiomas might a chance to be connected with life-undermining complications, for example, extreme bleeding, respiratory compromise, congestive heart failure, or liver disappointment [1]. Assessed on influence up to 4\% on 5\% for caucasian infants, they have been accounted in familial groups with a autosomal predominant pattern; however, the lion's share about instances happen sporadically. Referred to danger figures incorporate low conception weight, caucasian ethnicity, female gender, propelled maternal age, What's more an assortment from claiming prenatal difficulties (counting placenta previa What's more preeclampsia) [2]. Childish hemangiomas need aid commonly described Eventually Tom's perusing fast development Throughout those principal weeks with months about life, trailed Toward An variable plateau What's more an involution stage in which spontaneous relapse happens again a time from claiming months to quite some time [3]. In the vast majority cases, An finding could a chance to be committed clinically, In view of those presence of the lesion, and additionally those timing for its manifestation What's more its generally Growth design. Histologic examination Throughout the proliferative stage uncovers shallow proliferating endothelial units with couple of slim lumina. The involution stage may be portrayed Toward fibrosis from claiming slim lumina [2]. The correct pathogenesis from claiming $\mathrm{IH}$ will be incompletely understood, In spite of markers not communicated done ordinary dermal or subcutaneous tissues would every now and again distinguished for IH. Clinched alongside particular, vascular endothelial Growth variable (VEGF), glucose transporter-1 (GLUT-1), What's more placenta-associated vascular antigens (i. E. , FcrRII, merosin, Also lewis Y antigen) would Exceptionally communicated in the endothelial units of IH All around both those fast development stage and the involution stage. Interestingly, the main other vascular tissue referred to on impart An comparative outflow profile is from placental chorionic villi. Exactly current test proof proposes that IH might infer from clonal proliferations of endothelial phones through those de novo structuring from claiming primitive blood vessels 
starting with angioblasts [4]. The backbone about help for IH may be dynamic noninterference (i. E. , watchful waiting) as A large portion lesions are uncomplicated What's more will involute spontaneously without huge sequelae. However, mediation is frequently all the obliged to a clinically critical subset from claiming IH that need aid creating extreme organ brokenness (such Likewise congestive heart disappointment or liver failure), utilitarian hindrance (such Likewise debilitation about vision, feeding, or breathing), or huge cosmea disfigurement (such Concerning illustration huge facial, nasal tip, lip, breast, What's more genital lesions) [3]. To Numerous years, the first-line therapeutic medication for convoluted lesions might have been corticosteroids, including topical, intralesional, Also systemic methodologies. Unfortunately, corticosteroids were conflicting done viability Also systemic medicine might have been loaded for unfriendly side effects, including those improvemen about Cushingoid features, gastroesophageal reflux, hypertension, development retardation, and expanded defenselessness will contamination [5] However, An significant achievement happened over 2008 The point when Leaute-Labreze et al watched that an aggregation from claiming kids with $\mathrm{IH}$ who accepted help with the nonselective beta-blocker propranolol encountered checked change over their lesions [6].

This ponder pointed will analyze the middle of those impact for utilizing nearby corticosteroids (metamethasone), systemic beta blocker (Propranolol) Also both joined together in the oversaw economy from claiming heamangiomas On pediatrics.

\section{Patients and methods}

This was a prospective study that conducted at Benha university hospital and Benha children hospital on patient with heamangioma .

\section{Inclusion criteria}

pediatric patients aged below 6 yrs with heamangioma.

\section{Exclusion criteria}

Patients who underwent previous form of treatment for the heamangioma 2.patients with medical conditions contraindicating the use of corticosteroids or B-blockers.

\subsection{Methods}

patients with heamangioma who match inclusion criteria were divided randomly into three groups

Group A : 20 patients in this group was undergone intralesional injection of corticosteroid (betamethasone) at a dose of 10 to $40 \mathrm{mg} / \mathrm{ml}$ in 5 separate sessions with an interval of 3 weeks

Group B: 20 patients in this group were given oral b-blocker (propranolol) of $2-3 \mathrm{mg} / \mathrm{kg} /$ day for 4 months
Group C: 20 patient in this group were given both oral B-blocker (Propranlol) and intralesional injection of corticosteroid (Betamethasone) for 4 months.

\section{Ethical consideration}

- A fully informed consent was obtained from the parents regarding the type of treatment and the potential complications.

- Patients were initially evaluated regarding the first presentation of the hemangioma, the course of its growth, the complications if present and any associated diseases.

\section{All patients were subjected to the following}

Examination will be done including weight, growth chart evaluation for similar age group, blood pressure, heart rate, blood glucose and a complete systemic examination.

\section{- In Group A patients}

Local injection of betamethasone were done using a 22-gauge needle until blanching of the hemangioma is observed. According to the initial size of the hemangioma and the response to treatment the number of sessions was calculated.

\section{- In Group B patients}

were received oral B-blocker in the form of (propranolol according to $2-3 \mathrm{mg} / \mathrm{kg} /$ day in three divided doses per day for 4 months) parents was educated about the potential complications such as vomiting, constipation, hypoglycemia and hypotension, They were advised to keep a record of their child's blood pressure and blood sugar at a regular interval of 2 weeks.

\section{- In group C patients}

Patients were received both oral B-blocker (Propranlol) and intralesional injection of corticosteroid (Betamethasone) for 4 months

\section{Follow up}

Monthly follow-up of the effect of treatment was assessed by the following:

1-Alteration of size and colour of the hemangioma in response to treatment by serial photographs and monthly measurements.

2-Complications due to type of treatment, for example hypotension with oral b-blockers.

3- Cosmetic end-result

4- Time of response to treatment

Comparing the three groups of patients group will help us evaluate the best way in management of infantile cutaneous hemangioma and identify types and rate of complications occurring with each type of treatment.

\subsection{Statistical analysis}

The data were coded, entered and processed on computer using SPSS (version 18). The results were represented in tabular and diagrammatic forms then interpreted. Mean, standard deviation, 
range, frequency, and percentage were use as descriptive statistics. The following test was done: ChiSquare test $\mathrm{X}^{2}$ was used to test the association variables for categorical data. Student's t-test was used to assess the statistical significance of the difference between two population means in a study involving independent samples. $\mathrm{P}$ value was considered significant $\leq 0.05$ : Significant.

\section{Results}

There was no statistically significant difference between Group A, Group B and Group C regarding Sex Table (1).

There was no statistically significant difference between Group A, Group B and Group C regarding Age (months) Table (2).

There was statistically significant increase in Group A than Group B. There was no statistically significant difference between Group A and Group C. There was statistically significant decrease in Group B than Group C Table (3).

There was statistically significant difference between Group A, Group B and Group C regarding Site Table (4).
There was statistically significant increase in Group A than Group B. There was statistically significant increase in Group A than Group C. There was no statistically significant difference between Group B and Group C Table (5).

There was statistically significant between Group A and Group B than Group C, regarding lightening of colour Table (6).

There was no statistically significant between Group A, Group B and Group C regarding Complications Table (7).

There was statistically significant between Group A and Group B than Group C, regarding recurrence after $6 \mathrm{~m}$. No recurrence occurred among Group $\mathrm{C}$, recurrence occurred in $20 \%$ among Group B, $10 \%$ in Group A Table (8).

Mean difference of Group A (18.90), Group B (12.64) and Group C (19.38), so Group C is better than Group A, Group B Table (9)

There were statistically significant positive Original Hemangioma Size $(\mathrm{cm})$ and Size at 6 months among Group $\mathrm{C}$, But no statistically significant correlation between Original Hemangioma Size $(\mathrm{cm})$ and Size at 6 months among Group A and Group B Table (10).

Table (1) Comparison between Group A, Group B and Group C regarding Sex.

\begin{tabular}{llllllll}
\hline & & & Group A & Group B & Group C & $\mathbf{X}^{2}$ & P. value \\
\hline Sex & female & No. & 12 & 12 & 10 & .543 & 0.762 \\
& & $\%$ & $60.0 \%$ & $60.0 \%$ & $50.0 \%$ & & \\
& \multirow{4}{*}{ male } & No. & 8 & 8 & 10 & & \\
& $\%$ & $40.0 \%$ & $40.0 \%$ & $50.0 \%$ & & \\
\hline
\end{tabular}

Table (2) Comparison between Group A, Group B and Group C regarding Age (months).

\begin{tabular}{|c|c|c|c|c|c|c|}
\hline & & Group A & Group B & Group C & f.test & P. value \\
\hline $\begin{array}{l}\text { Age } \\
\text { (months) }\end{array}$ & Mean \pm SD & $13.80 \pm 4.15$ & $10.40 \pm 4.031$ & $13.10 \pm 5.955$ & 2.805 & .069 \\
\hline
\end{tabular}

Table (3) Comparison between Group A, Group B and Group C regarding Original Hemangioma Size $(\mathrm{cm})$.

\begin{tabular}{|c|c|c|c|c|c|c|c|}
\hline & & Group A & Group B & Group C & f.test & P. value & p \\
\hline $\begin{array}{l}\text { Original } \\
\text { Hemangioma Size } \\
\text { (cm) }\end{array}$ & Mean \pm SD & $18.90 \pm 5.06$ & $12.64 \pm 5.52$ & $19.38 \pm 6.94$ & 8.145 & .001 & $\begin{array}{l}\mathrm{P} 1=0.001 \\
\mathrm{P} 2=0.798 \\
\mathrm{P} 3=0.001\end{array}$ \\
\hline
\end{tabular}

P1 = between Group A and Group B, P2 = between Group A and Group C, P3 = between Group B and Group C.

Table (4) Comparison between Group A, Group B and Group C regarding Site.

\begin{tabular}{|c|c|c|c|c|c|c|c|}
\hline & & & Group A & Group B & Group C & $\mathbf{X}^{2}$ & P. value \\
\hline \multirow[t]{8}{*}{ Site } & abdomen & No. & 2 & 4 & 4 & 45.800 & .001 \\
\hline & & $\%$ & $10.0 \%$ & $20.0 \%$ & $20.0 \%$ & & \\
\hline & arm & No. & 0 & 0 & 4 & & \\
\hline & & $\%$ & $.0 \%$ & $.0 \%$ & $20.0 \%$ & & \\
\hline & back & No. & 2 & 2 & 4 & & \\
\hline & & $\%$ & $10.0 \%$ & $10.0 \%$ & $20.0 \%$ & & \\
\hline & buttock & No. & 2 & 0 & 0 & & \\
\hline & & $\%$ & $10.0 \%$ & $.0 \%$ & $.0 \%$ & & \\
\hline
\end{tabular}


Table (4) Continue

\begin{tabular}{ccccc}
\hline Cheek & No. & 0 & 2 & 0 \\
& $\%$ & $.0 \%$ & $10.0 \%$ & $.0 \%$ \\
chest & No. & 4 & 0 & 4 \\
& $\%$ & $20.0 \%$ & $.0 \%$ & $20.0 \%$ \\
face & No. & 0 & 6 & 0 \\
& $\%$ & $.0 \%$ & $30.0 \%$ & $.0 \%$ \\
Periorbital & No. & 0 & 2 & 0 \\
& $\%$ & $.0 \%$ & $10.0 \%$ & $.0 \%$ \\
scalp & No. & 6 & 4 & 2 \\
shoulder & $\mathbf{\%}$ & $30.0 \%$ & $20.0 \%$ & $10.0 \%$ \\
& No. & 2 & 0 & 0 \\
& $\mathbf{\%}$ & $10.0 \%$ & $.0 \%$ & $.0 \%$ \\
thigh & No. & 2 & 0 & 2 \\
& $\mathbf{\%}$ & $10.0 \%$ & $.0 \%$ & $10.0 \%$ \\
\hline
\end{tabular}

Table (5) Comparison between Group A, Group B and Group C regarding Size at 6 months.

\begin{tabular}{llcccccc}
\hline & & Group A & Group B & Group C & f.test & P. value & p \\
\hline Size at & 6 Mean \pm SD & $7.08 \pm 2.38$ & $3 \pm 3.49$ & $2.87 \pm 3.67$ & 10.977 & .000 & P1 $=0.000$ \\
months & & & & & & P2 $=0.000$ \\
& & & & & & & P3 $=0.896$ \\
\hline
\end{tabular}

P1 = between Group A and Group B, P2 = between Group A and Group C, P3 = between Group B and Group C.

Table (6) Comparison between Group A, Group B and Group C regarding lightening of colour.

\begin{tabular}{lccccccc}
\hline & & & Group A & Group B & Group C & $\mathbf{X}^{2}$ & P. value \\
\hline Lightening of & no & No. & 6 & 4 & 1 & 4.230 & .021 \\
colour & & $\boldsymbol{\%}$ & $30.0 \%$ & $20.0 \%$ & $5.0 \%$ & & \\
& yes & $\begin{array}{c}\text { No. } \\
\text { \% }\end{array}$ & 14 & $70.0 \%$ & $80.0 \%$ & $95.0 \%$ & \\
\hline
\end{tabular}

Table (7) Comparison between Group A, Group B and Group C regarding Complications.

\begin{tabular}{lccccccc}
\hline & & & Group A & Group B & Group C & $\mathbf{X}^{2}$ & P. value \\
\hline Complications & No & No. & 18 & 20 & 20 & 4.138 & 0.126 \\
& \multirow{4}{*}{ ulceration } & $\mathbf{\%}$ & $90.0 \%$ & $100.0 \%$ & $100.0 \%$ & & \\
& & No. & 2 & 0 & 0 & & \\
& & $\mathbf{\%}$ & $10.0 \%$ & $.0 \%$ & $.0 \%$ & & \\
\hline
\end{tabular}

Table (8) Comparison between Group A, Group B and Group C regarding recurrence after 6m.

\begin{tabular}{lccccccc}
\hline & & & Group A & Group B & Group C & $\mathbf{X}^{\mathbf{2}}$ & P. value \\
\hline $\begin{array}{l}\text { Recurrence } \\
\text { after 6m }\end{array}$ & no & No. & 18 & 16 & 20 & 4.444 & 0.04 \\
& & $\%$ & $90.0 \%$ & $80.0 \%$ & $100.0 \%$ & & \\
& yes & No. & 2 & 4 & 0 & & \\
& & $\%$ & $10.0 \%$ & $20.0 \%$ & $.0 \%$ & & \\
\hline
\end{tabular}

Table (9) Relation between Original Hemangioma Size (cm) and Size at 6 months among and Group C.

\begin{tabular}{lcccccc}
\hline & & $\begin{array}{c}\text { Original Hemangioma } \\
\text { Size }(\mathbf{c m})\end{array}$ & $\begin{array}{c}\text { Size at 6 } \\
\text { months }\end{array}$ & $\begin{array}{c}\text { Mean } \\
\text { difference }\end{array}$ & $\begin{array}{c}\text { Paired t } \\
\text { test }\end{array}$ & P. value \\
\hline Group A & Mean + SD & $18.90 \pm 5.06$ & $7.08 \pm 2.38$ & 11.82 & 9.015 & 0.000 \\
& & & & & & \\
Group B & Mean + SD & $12.64 \pm 5.52$ & $3 \pm 3.49$ & 9.64 & 8.196 & 0.000 \\
Group C & Mean + SD & $19.38 \pm 6.94$ & $2.87 \pm 3.67$ & 16.51 & 13.184 & 0.000 \\
\hline
\end{tabular}


Table (10) Correlation between Original Hemangioma Size $(\mathrm{cm})$ and Size at 6 months among Group A, Group B and Group C.

\begin{tabular}{lcc}
\hline \multicolumn{1}{c}{ Correlation } & \multicolumn{2}{c}{$\begin{array}{c}\text { Pearson's } \\
\text { correlation }\end{array}$} \\
\cline { 2 - 3 } & \multicolumn{1}{c}{$\mathbf{p}$} & $\mathbf{p}$ \\
\hline Original Hemangioma Size $(\mathbf{c m})$ and Size at 6 months among Group A & $-.130-$ & .586 \\
Original Hemangioma Size $(\mathbf{c m})$ and Size at 6 months among Group B & .386 & .093 \\
Original Hemangioma Size $(\mathbf{c m})$ and Size at 6 months among Group C & .594 & .006 \\
\hline
\end{tabular}

\section{Discussion}

This investigation showed, guys might have been (43. 3\%) What's more females might have been (56. $7 \%)$.

This agrees with [7] who discovered that, reliable with the ones depicted in the past inside the literature, for An predominance from claiming females, with ages went starting with 1-11 months. [8] who found that, there were more guys over females (3:2).

This contemplate showed, The greater part normal might have been scalp (20\%), taken after Eventually Tom's perusing abdomen (16. 7\%), midsection (13. $3 \%)$, over (13. $3 \%$ ) What's more face might have been $(10 \%)$.

who found that, upper limbs inclusion might have been A large portion as a relatable point representing 18 (28. 6\%), accompanied Toward face/neck 12 (19. $1 \%)$, same time axillary Furthermore intra-oral hemangioma accounted individually to $3(4.8 \%)$ cases [9].

news person that, in regards site of IHs, more excellent over $60 \%$ for IHs happen on the face, head Also neck[10].

noted Cushingoid facies $(71 \%)$, customized progressions (21\%), gastric aggravation (21\%), contagious contamination[11] .

(6\%) Also reversible myopathy (one patient) in 62 patients getting systemic steroid help to problematic IHs. Same time practically difficulties are transient Furthermore limited, A percentage might get to be a great deal that's only the tip of the iceberg serious, for example, such that hypertension Also hypertrophic obstructive cardiomyopathy.

noted behavioral progressions such as irritability/insomnia (25\%), poor stature pick up (8\%) and hypertension (5\%) Throughout prednisone treatment. Cushingoid facies might have been watched to Different extents altogether children, In spite of they required catch-up development after end of help for no gastric aggravation alternately infections. Done our study, prednisolone medication prompted Cushingoid presence for half trailed Eventually Tom's perusing GI upset (30\%) On gathering b. Previously, addition, there might have been regrowth In the wind about every 3week cycle for $30 \%$ instances. Disappointment to flourish In 18 months about catch up (weight b5th centile) and contamination requiring stopping of prednisolone were seen over $10 \%$ each. To gathering $\mathrm{C}, 70 \%$ patients required person or a greater amount complications, The greater part about them once more initiated Eventually Tom's perusing prednisolone in particular Cushingoid features (60\%), GI furious (40\%), regrowth (10\%) Also spoiling (10\%). Same time the vast majority difficulties relapse for stopping about therapy, they cause a considerable measure for anguish should guardian alternately oblige withholding treatment for some time. Propranolol, a well-tolerated, nonselective, $\beta$-adrenergic receptor blocker needed been regularly utilized to cardiologic signs to adolescent kids[12].

To 2008, [6] accounted for those coincidental discovering that it Might control the Growth about IHs proficiently. Different investigations finished from that point forward bring indicated a phenomenal impact Also useful tolerance [13].

Inside hours about beginning therapy, it produces vasoconstriction, bringing about a decrease in the shade of the hemangioma. Its essential impact gives the idea will a chance to be modification in the progression of angiogenesis, maybe Eventually Tom's perusing diminishing outflow of essential fibroblast development element (bFGF) What's more vascular endothelial Growth element (VEGF) [6].

It might ablate catecholamine receptor signaling, diminishing cyclic amp pushing involution Eventually Tom's perusing activating apoptosis clinched alongside endothelial phones [14].

On our study, intend distinction about span of hemangioma for gathering An (18. 90), aggregation b (12. 64) Furthermore assembly c (19. 38), In this way aggregation c's will be superior to gathering $\mathrm{A}$, one assembly b. [8] discovered that, intend reaction time in patients accepting prednisolone alone might have been $9.78 \pm 7.8$ days, which might have been essentially more (p b 0. 047) over patients getting propranolol alone or blending about both. Mean decrease On extent from claiming more than $25 \%$ during 1 month might have been main $10 \%$ On one assembly b. There might have been no included playing point for joining two pills As far as reaction time.

A meta-analysis also discovered reaction rates with $\beta$-blockers on make superior, reporting weight $69 \%$ versus $97 \%(\mathrm{p}<0.001)$ to corticosteroids What's more propranolol, individually [1,12] approached proliferating IHs for systemic corticosteroids during An measurements from claiming $2 \mathrm{mg} / \mathrm{kg} / \mathrm{d}$ as first-line medicine for $23(56 \%)$ Also Concerning illustration second-line help then afterward disappointment for laser or cryotherapy Previously, 18 (44\%). Mean span for treatment might have been 129. 0 What's more 137. 
6 days individually. Viability following 2 weeks of therapy, characterized Similarly as more than $25 \%$ shrinkage, might have been noted clinched alongside $86 \%$ in the primary aggregation and On the whole provided for Concerning illustration second-line help.

Over an alternate study, propranolol Might a chance to be suspended Previously, 15 of the 32 cases, In ages going starting with 6 with 14 months (mean 9. 4 months) [15].

Dealt with 58 Youngsters for propranolol (dose 1. $0-1$. $5 \mathrm{mg} / \mathrm{kg} / \mathrm{d}$ ). Those result might have been phenomenal to 17. $2 \%$, great clinched alongside 60 . $4 \%$, moderate for $20.7 \%$ and poor for $1.7 \%$ for instances[16].

Assessed 32 Patients Approached With Propranolol (Dose $2 \mathrm{Mg} / \mathrm{Kg} / \mathrm{D}$ ) Toward Clinical Examination (Treating Physicians) Also Evaluation About Photographs By Blinded Physicians, Uncovering Half For Patients On Be Fantastic Responders, 47\% Fractional Responders What's More 3\% Nonresponders. Minor Unfriendly Impacts Incorporated Sluggishness Done 27\% About Patients, Gastroesophageal Reflux Clinched Alongside 9\%, Respiratory Syncytial Infection Worsening Alternately Rash On 4. 5\%.[17]

For A Review Study Dealt With 71 Patients Of Ihs For Propranolol (Dose $2 \mathrm{Mg} / \mathrm{Kg}$ ). At 20 Weeks, The Normal Diminishment Might Have Been 60\% Anyway After That Lesquerella Great Measure Decrease Might Have Been Gotten[14].

For our study, those The greater part incessant muddling of IHs might have been ulceration which struck them for $10 \%$ from claiming one assembly some time not happened On bunch b or aggregation c's.

The mossycup oak incessant muddling of IHs is ulceration happening done up to $15 \%$ of patients and may be a test should oversee [18].

It camwood prompt pain, irritability, poor nourishing or sleeping, scarring, Also distortion [10].

It will be likewise connected with dying (41\%) and contamination (16\%) [19].

Contributory Components incorporate surface rubbing What's more maceration [18].

[8] found that, ulceration might have been seen in 4 (13. 3\%) patients with dying done $75 \%$ Also spoiling over $25 \%$. An extensive scapular hemangioma approached for propranolol alone indicated stoppage of dying inside 24 hours Also recuperating for ulcer inside 3 months. Whatever remains gained An blending from claiming propranolol Furthermore prednisone Similarly as for every randomization. Two of these mended totally inside a month. In turn contaminated lower arm hemangioma needed stopping for prednisolone Also mended On 2 months for propranolol best.

This might have been tantamount to the examine led Eventually Tom's perusing [15] on 32 patients the place frightful ulcerations mended totally inside 2 months about propranolol treatment. Two different little arrangement about ulcerated IH need demonstrated punctual Also great light of oral propranolol at An measurement of $1-2 \mathrm{mg} / \mathrm{kg}$ for every day for no side impacts [20].

This investigation showed, there might have been statistically noteworthy the middle of aggregation a Furthermore bunch $\mathrm{b}$ over bunch $\mathrm{C}$, in regards to repeat after $6 \mathrm{~m}$. No repeat struck them "around one assembly C, repeat struck them for $20 \%$ "around assembly B, $10 \%$ Previously, assembly a.

news person repeat over 2 of the 14 patients who finished medication with propranolol toward $2 \mathrm{mg} /$ $\mathrm{kg} / \mathrm{d}$ for what added up to 11 and 8.5 months. Treatment might have been halted during the period from claiming 14. 3 Also 12. 5 months, separately. Gentle regrowth and obscuring for shade were noted 8 weeks following discontinuing treatment. Both moved forward ahead restarting propranolol[13].

discovered that, no repeat might have been seen over one assembly An. Information viewing similar viability of steroid What's more propranolol and impact from claiming solitary versus blending of two medications are insufficient despite those secondary frequency for IHs. To gathering $\mathrm{C}$, there might have been regrowth to best $10 \%$ contrasted with $30 \%$ On one assembly $\mathrm{B}$, demonstrating those viability of the expansion from claiming propranolol[8].

news person utilization of propranolol clinched alongside 30 IHs. Those Normal agdistis at the begin from claiming help might have been 5. 8 months (range 1. 2-13. 5 months) initiated at a dosage of $1 \mathrm{mg} / \mathrm{kg} / \mathrm{d}$ expanded to $2 \mathrm{mg} / \mathrm{kg} / \mathrm{d}$ after 1 week. Nine were approached then afterward disappointment to react on corticosteroids. Two were approached for both prednisolone Furthermore propranolol, same time whatever remains accepted main propranolol. Nineteen babies effectively finished medication and the remaining exhibited huge change. Those greater part responded inside a week of initiating propranolol. No noteworthy unfriendly impacts were accounted[21].

Contrasted with past medication (systemic corticosteroids), propranolol needed been demonstrated will be connected with finer Also quicker reaction with fewer unfriendly impacts [22, 23]. [24] news person a newborn child with a subglottic Furthermore mediastinal hemangioma who Hosting neglected past endeavors In surgical resection might have been place once a blending about oral propranolol $(2 \mathrm{mg} / \mathrm{kg} / \mathrm{d})$ Also prednisolone $(3 \mathrm{mg} / \mathrm{kg} / \mathrm{d})$. Those patient's stridor determined inside 2 days for beginning drug medicine. An mri performed a week later uncovered An half decrease Previously, extent. Prednisolone might have been decreased off toward that time, same time those propranolol might have been proceeded for 5 months. It might have been decreased off for no repeat for side effects.

discovered that $82 \%$ for patients in the propranolol aggregation moved forward Eventually Tom's perusing $75 \%$ alternately more, compared with $29 \%$ of patients in the steroid aggregation. Person tolerant on propranolol required hypoglycemia, Be that know 
patients in the steroid gathering required in any event one unfriendly off chance. Those propranolol treatment might have been something like half those expense about steroid help. They inferred that propranolol ought to be acknowledged a first-line help for IHs. Viability What's more reaction profile show up that's only the tip of the iceberg positive position with propranolol contrasted with prednisolone alone or Previously, consolidation Furthermore if trade help with steroids in the oversaw economy for IHs, particularly convoluted ones[25].

\section{Conclusion}

In this study we found significantly better outcome in the combined treatment group compared to monotherapy groups.

\section{References}

[1] S. Shah, I. J. Frieden Treatment of infantile hemangiomas with beta-blockers: a review. Skin Therapy Lett. Vol.18(6), PP.5-7, 2013.

[2] H. P. Nguyen, B. B. Pickrell , T. S. Wright, (). Beta-blockers as therapy for infantile hemangiomas.Seminars in plastic surgery. Vol. 28(2), PP.87-90,2014.

[3] L. C. Chang, A. N. Haggstrom, B .A. Drolet , Growth characteristics of infantile hemangiomas: implications for management. Pediatrics. Vol.122(2), PP.360-367,2008.

[4] C. M. Barnés , S. Huang, A. Kaipainen, Evidence by molecular profiling for a placental origin of infantile hemangioma. ProcNatlAcadSci U S A. vol.102(52), PP.19097-19102,2005.

[5] M. E. Kelly, A.M. Juern, W.J. Grossman, , Immunosuppressive effects in infants treated with corticosteroids for infantile hemangiomas. Arch Dermatol. vol.146(7), PP.767-774, 2010.

[6] C. Léauté-Labrèze, E .Dumas de la Roque, T .Hubiche, Propranolol for severe hemangiomas of infancy. N Engl J Med. vol. 358, PP.2649-51, 2008.

[7] I. M. El-Sayaad, M. A. E Shahin, S. Abdelmonem, Comparative Study Between Systemic And Topical Propranolol In Treatment Of Infantile Hemangiomas. Al-Azhar Medical J., Vol. 46(2),PP. 363-372, 2017.

[8] M. A. Malik, P. Menon, K. L. N. Rao, R. Samujh, Effect of propranolol vs prednisolone vs propranolol with prednisolone in the management of infantile hemangioma: A randomized controlled study. Journal of Pediatric Surgery, 48(12), 2453-2459. doi:10.1016/j.jpedsurg., vol . 08, PP.020, 2013.

[9] O. David Osifo, I. Evbuomwan, Hemangiomas in children: challenges and outcome of surgical management in benin city, Nigeria. Iranian journal of pediatrics. Vol. 21(3), PP.350-356, 2011.

[10] A.N. Haggstrom, B.A. Drolet, E. Baselga Prospective study of infantile hemangiomas: demographic, prenatal, and perinatal characteristics. J Pediatr. vol.150(3), PP.291-294, 2007.

[11] L.M. Boon, O. Enjolras, J.B. Mulliken, Congenital hemangioma: evidence of accelerated involution. J Pediatr., vol.128, PP.329-34,1996.

[12] J. Rössler , G. Wehl, C.M. Niemeyer, Evaluating systemic prednisone therapy for proliferating haemangioma in infancy. Eur J Pediatr., Vol.167, PP.813-5, 2008.

[13 C. Schiestl, K .Neuhaus, S. Zoller, Efficacy and safety of propranolol as first-line treatment for infantile hemangiomas. Eur J Pediatr., Vol.124, PP.423-31,2010.

[14] L. Bagazgoitia, A. Hernández-Martín, A. Torrelo. Recurrence of infantile hemangiomas treated with propranolol. PediatrDermatol,.vol.28(6), PP.658662, 2011.

[15] V. Sans, E. Dumas de la Roque, J. Berge, Propranolol for severe infantile hemangiomas: follow-up report. Pediatrics., vol.24, PP.423-31, 2009.

[16] Z.P. Qin, X.J. Liu, K.L. Li, Treatment of infantile hemangiomas with low-dose propranolol: evaluation of short-term efficacy and safety. Zhonghua Yi Xue Za Zhi., Vol.89 ,PP.3230-4, 2009.

[17] L.M. Buckmiller, P.D. Munson, U. Dyamenahalli, Propranolol for infantile hemangiomas: early experience at a tertiary vascular anomalies center. Laryngoscope. Vol.120, PP.676-81, 2010.

[18] A. Pandey, A.N. Gangopadhyay, S.P. Sharma, Conservative management of ulcerated haemangioma-twenty years experience. Int Wound J. vol6, PP.59-62, c2009.

[19] S.L. Chamlin, A.N. Haggstrom, B.A. Drolet, Multicenter prospective study of ulcerated hemangiomas. J Pediatr. Vol.151, PP.684-9, 2007.

[20] L.H.C. Kima, M. Hogeling, O. Wargon,. Propranolol: useful therapeutic agent for the treatment of ulcerated infantile hemangiomas. J Pediatr Surg. Vol.46, PP.759-63, 2011.

[21] F. Manunza, S. Syed, B. Laguda,. Propranolol for complicated infantile haemangiomas: a case series of 30 infants. $\mathrm{Br} \mathrm{J}$ Dermatol.vol.162, PP.466-8,2010.

[22] C. Fuchsmann, M.C. Quintal, C. Giguere, Propranolol as first-line treatment of head and neck hemangiomas. Arch Oto laryngeal Head Neck Surg., Vol. 137, PP.471-8, 2011.

[23] A. Balma-Mena, A .Chakkittakandiyil, M. Weinstein, Propranolol in the management of infantile hemangiomas: clinical response and predictors. J CutanMed Surg., Vol. 16, PP.16973,2011.

[24] M.T. Truong, K.W. Chang, D.R. Berk, Propranolol for the treatment of a life-threatening subglottic and mediastinal infantile hemangioma. J Pediatr., Vol.156, PP.335-8, 2010. 
[25] C.J. Price, C. Lattouf, B. Baum, Propranolol vs. corticosteroids for infantile hemangiomas: a multicenter retro-spective analysis. Arch Dermatol. Vol. 147, PP.1371-6, 2011. 